\title{
TAITEELLISTA TUTKIMUSTA ELÄMÄNMUOTOMME AINEKSISTA
}

\author{
Timo Heino: Aineen olemuksesta \\ materian muuntumiin. Taideyliopiston \\ Kuvataideakatemia, Helsinki, 254 sivua.
}

Miten tutkia aikalaiselämäntapaa? Jotta arkisesti itsestään selvää maailmaa voisi tarkastella, sen tuttuus on tavalla tai toisella tehtävä vieraaksi. Sellaista ei voi lähestyä, minkä keskellä ja osana jo on. On luotava liike läheisyyden ja etäisyyden välillä. "Lähestysmistapa”, englanniksi approach, vaatii siis vastinparikseen jotain sellaista, mikä englanniksi olisi detachment-ja hieman tarkoitushakuisesti kääntäen vanhaksi kreikaksi theorein, katsetta etäisyyden päästä. Yhteiskuntatieteilijöille ensisijaiseksi oman elämänmuodon tutkimuksen välineeksi ei kuitenkaan yleensä ehdoteta teoreettisuutta vaan tutkimusvälineitä, jotka jaetaan kahteen pääasialliseen luokkaan, "laadullisiin" ja "määrällisiin" menetelmiin. Kun taidealan jatkokoulutusta on viime vuosina rakennettu muulle yliopistomaailmalle yhteismitalliseksi, institutionaalinen tilanne on samalla kannustanut sellaisen tutkimuksen kehittämistä, jonka väline on jotain kolmatta, jotain erilaista kuin edes laadullisiksi yleensä nimetyt tutkimusmenetelmät, mutta jonka kohde saattaa taiteen lisäksi olla aikalaiselämänmuotomme. Tällaisen tutkimuksen mahdollisuuksista Timo Heinon Aineen olemuksesta materian muuntumiin on hyvä esimerkki.

Työssään Heino kysyy, "mitä aineet, ainesyhdistelmät ja -koosteet tuovat ilmi, jos niitä tarkastellaan sosiaalisten käyttäytymissääntöjen, rajattujen päämäärien ja tavanomaisten käyttötarkoitusten ulkopuolella" (s. 19). Kirja vastaa tähän kysymykseen kolmella tavalla: sekä itsenäisenä käsitteellisenä tutkimuksena, väitöstyöhön kuuluvien taiteellisten produktioiden esittelynä että kuvauksena Heinon koko taiteellisen tuotannon kehittymisestä, sen vaikutteista ja menetelmistä.

Käsitteellistämisen näkökulmasta tärkeimpiä ovat teoksen kaksi ensimmäistä lukua. Niissä Heino kuvaa, miten väitöskirjan aihepiiri ja siihen liittyvä tutkimuksellinen ote on kehittynyt hänen aikaisemmissa produktioissaan ja miten häntä on tässä työssä innoittanut niin yhteiskuntatieteellinen, filosofinen kuin luonnontieteellinenkin kirjallisuus. Heino asemoi työnsä sekä taiteen kentälle että suhteessa sellaisiin käsitteellisiin jakoihin, joita hän pitää aikalaisyhteiskuntamme kannalta keskeisinä. Avainkysymys koskee materiaalisuutta: elämänmuotomme ainesten suhteita ja niihin liittyviä raja-alueita, ulos sulkemisia ja torjumisia. Aineellisuuden monimuotoisuus ja muuntuvuus tulee esiin varsinkin suhteessa puhtautta ja likaisuutta koskeviin luokitteluihin. Pontimena on näyttää, kuinka toisiaan vasten yleensä määritellyt asiat, kuten "luonto" ja "kulttuuri" tai "henki" ja "ruumis", kietoutuvat toisiinsa, kuinka tällaisten kaksinaisuuksien navat moninaistuvat tai kuinka niiden jäsenet liudentuvat toisiinsa.

\section{TAITEELLISET PRODUKTIOT}

Lukujen yksi ja kaksi käsitteellisten ja tutkimushistoriallisten erittelyjen jälkeiset viisi lukua tarkastelevat kukin yhtä väitöstyön kokonaisuuteen kuuluvaa taiteellista produktiota. Ansiokasta kirjassa on, että tässä kohtaa tekstiin ei tule ajatuksellista katkosta. Taiteel- 
liset työt todella ovat yhteydessä käsitteellisiin kehittelyihin mutta tuovat esiin näihin nähden myös täysin erilaisen ulottuvuuden.

Ensimmäinen esiteltävistä produktioista on "Koivuniemen herra" -installaatio. Se koostuu synteettiseen kumiin puetusta kelomännystä, jonka oksiin on liimattu linnunmunia. Teos asettaa toisiaan vasten orgaanisia ja teollisia elementtejä ja tematisoi haurauden, painovoiman ja fetisismin lisäksi syntytarinansa kautta muistamisen paikka- ja ainessidonnaisuuden: kelohonka on sahattu Heinolle henkilöhistoriallisesti tärkeältä kalliolta ennen alueen rakentamista. Tätä seuraava luku käsittelee työtä nimeltä "Parrakas neitsyt". Siinä Heino on piirtänyt valokaapin pinnalle ihokarvoillaan omakuvansa karvoituksen jälkinä. Teos tarkastelee muun muassa ruumiin rajoja sekä puhtaan ja likaisen suhdetta niihin mutta myös piirtämistä taiteen menetelmänä ja valoa sen olemisen ehtona. Heino kiteyttää työn tarkoituksen seuraavalla tavalla (s. 147): "Eläimelliset karvat ovat puhtaassa valopinnassa epätäydellisen ihmisruumiin merkki, tahra, valon läpäisemä lihaton piirrustus; valoon sulautuneen ja kadonneen ruumiin jälki. Samalla karvoituksen voi hauraudessaan nähdä korostavan valon aineellisuutta, teknologista kirkastumista valon materialisoitumisena."

Kokonaisuuden kolmas teos on "Syljetty avaruus". Sen rakenteena on musta planetaarioteltta, jonka keskellä on himmeää valoa antava lamppu. Sisällä näkyvä tähtitaivas koostuu teltan kattoon liimatuista nikotiinipurukumeista. Teltan suuaukko on lyhyt käytävä, voimakkaan symbolinen raja sisä- ja ulkotilan välillä. Heinon töille tavanomaiseen tapaan tässäkin installaatiossa tematisoituu kerralla monta aihetta, kuten esimerkiksi valo, jätteet ja ruumiillisen himon hallinta. Sen loiston illuusion tähtinä ovat tähteet, syljetyt nikotiinipurukumin palat. Alkuräjähdyksenä on ollut tupakanhimo ja sen hallitsemisen hitaasti kerääntyneet jäljet, jotka on sijoitettu kohtumaiseen sisätilaan. Tuo sisätila tarjoaa kävijälle jonkinlaisen luontokokemuksen, joka on kuitenkin läpeensä keinotekoinen. Teos pelaa tehokkaasti käsityksillä etäisyyksista ja läheisyyksistä, tuttuudesta ja vieraudesta sekä sisäisyyden ja ulkoisuuden muuntuvuuksista. Minkälainen osa ihmisen elämän avaruutta ja ihmisen luontoa on nikotiinipurukumi, johon piirtyvät selkeinä purijan suun sisätilan ainutlaatuiset jäljet?

Kokonaisuuden toiseksi viimeisessä installaatiossa nimeltä "Kietoutumia" keskeiset hahmot ovat kaksi ikään kuin lentoasentoon ripustettua lapsimallinukkea, joiden päiksi on liimattu suuret ampiaispesät. Keinotekoisen mallinukke-elementin ja luonnonmuodon yhdistelmä herättää sekä häiriintyneen mielikuvan astronautista kypärineen että ajatuksen mallinuken vanhenemisesta ja pilaantumisesta, mahdollisuudesta muovin mädäntyä. Teoksen muita osia ovat näyttelytilaan sijoitetut erilliset ampiaispesät, yöperhosen siivet sekä kasvonaamio, jossa myös on aineksena ampiaispesiä mutta lisäksi selluloosaa ja Heinon omia hiuksia. Installaatiossa erilaiset ainekset ja niihin liittyvät assosiaatiot - mainonnan ihmiskuvasta vaarallisiin ampiaisenpistoihin - yhdistyvät jonkinlaiseksi "murtumaksi eläimen ja ihmisen rajalla" (s. 185). Heino tiivistää:"Muokkaamani nuket ovat paluuta olemassaolomme perimmiltään ambivalenttiin unheimlich-luonteeseen: siihen, ettei meitä peilissä katsova hahmo vastaa yksiselitteisesti sen paremmin kokemusta itsestä kuin myöskään kokemusta toisesta, vaan olemme itsellemmekin yhtä aikaa tuttuja, vieraita ja kätkettyjä" (s. 194).

Ajatus itsestä samanaikaisesti tuttuna, vieraana ja kätkettynä on keskeinen myös kirjassa viimeisenä esiteltävässä työssä nimeltä "Miehen puolikas". Äitinsä kuoleman jälkeen Heino on löytänyt lapsuudenkodistaan leikkinallen, joka on ollut hänen poikavuosiensa turvaesine. Hän on muokannut sitä siirtämällä sen kasvojen tilalle löytämänsä oikean karhunpoikasen kallon. Kuten edellisissä töissä, tässäkin turvallinen, kotoinen ja tuttu muuttuu kamalaksi - mutta ei täysin. Ajan kuluminen, kuoleman läsnäolo elämän keskellä sekä aikui- 
sen miehen samanaikainen etäisyys ja läheisyys omaan lapsuuteensa tulevat läsnäoleviksi työstetyn nallen kautta.

\section{KOKEELLISUUS MENETELMÄNÄ}

Aineen olemuksesta materian muuntumiin on rikas ja monitasoinen kirja. Kokoamisena ja koetteluna Heinon työ on moniskaalaista: siinä yhdistyvät hänen henkilöhistoriansa tarinat, yksittäiset käsityömäiset ratkaisut taiteellisissa teoksissa, teknologiset tuotokset ja teollisuuslaitosten valmisteet mutta myös kokonainen sivilisatorinen näkökulma elämäntapaamme, siihen, mitä Heino kutsuu "muovikaudeksi" (s. 78). Hän käyttää teostensa aineksena paljon henkilöhistoriaansa ja sen jälkiä, mutta omakohtainen ja kokemuksellinen ei kuitenkaan käy piinaavaksi itsetarkoituksellisuudessaan. Kysymys ei ole tunnustuksellisuudesta tai sensaatiomaisuuden tavoittelusta silloinkaan, kun töiden tarkoituksena on koetella hyvän maun rajoja ja hätkäyttää. Yksilökokemus ei näissä töissä ole liittymättä johonkin sitä yleisempään. Se on vain yksi mittakaava niiden monien joukossa, joiden väliä väitöskirjatyö kulkee.

Heinon keskeinen menetelmä taideproduktioissa on toisilleen vieraiden asioiden ja ilmiöiden rinnastaminen osana jotain täysin uudenlaista kokonaisuutta. Tuloksena on usein absurdiutta, outoja hahmoja, joihin on helppo yhdistää niin ilon kuin kivunkin tuntemuksia, rajoilla olemisen kokemusta. Yhdistelemällä tavallisesti etäisiksi nähtyjä elementtejä - esimerkiksi kerättyjä luonnontuotteita, teollisia prosesseja, valoa, liimaa, terästä ja muovia tai pölyä, purukumia ja hiuksia - Heino luo eräänlaisia kokoelmia, lajitelmia ja näytteitä elämäntapamme elementeistä ja niihin liittyvistä rinnastamisen kielloista. Tutkimuskysymyksen muotoilussa (s. 19) Heinon käyttämä ilmaisu "ilmi tuominen" on sattuva, sillä kysymys on toki esittämisestä esiin saattamisen merkityksessä mutta enemmästä ja muusta kuin kuvallisesta toistamisesta, representaatiosta.
Heinon tarkastelutapa ei ole aineelliselle maailmalle ulkopuolinen, ei kuvaa sitä toisaalta, henkisen kirkkauden illuusiossa. Sen sijaan hän työstää materiaaleja niiden keskeltä, ainesten sisältä, niitä muokaten ja niiden suhteita kokeillen. Hämmentävät ainesten yhdistelmät tuovat yhtältä ilmi, että jo nyt maailmamme koostuu mitä erilaisimmista liitoksista, jotka arjen keskellä kuitenkaan nimenomaan eivät hämmennä. Kokeellinen työ tuo siis tavanomaisuuksia esiin. Toisaalta tavoitteena on myös oudon tuottaminen, aivan uuden testaaminen. Etukäteen ei tiedetä, kestääkö liima, lentävätkö karvat valopinnalta pois ja pysyykö pöly kasassa.

On kuitenkin selvää, että Heinon harjoittama kokeilu tai eksperimentaatio eroaa siitä, mitä luonnontieteilijät tekevät. Tarkoitus ei ole tuottaa jotain, mikä todistaisi maailman tiloja tai mikä voitaisiin falsifioida seuraavissa kokeissa. Kokeet eivät myöskään tuota täsmällisiä tuloksia, eivät kerro tarkkoja vastauksia. Sen sijaan yhdet assosiaatiot avaavat tilaa toisille. Heinon työssä kokeellisuus merkitseekin sen tarkastelemista, minkälaisen älyllisen ja aistimellisen vaikutuksen yhdistämiset tuottavat, miten ne voivat synnyttää meille uudenlaisen ajattelun, havainnon ja kokemuksen tilan. Tällainen eksperimentaalisuus ei ole loppuun asti kontrolloitua. Ehkä päinvastoin se ennemminkin pyrkii vapauttamaan sellaisista kontrolleista, joiden olemassaoloa emme ole tienneet ennen näiden kokeiden tekemistä. Emme tiedä, mihin aineellisuutemme kykenevät ja mitkä niiden rajat ovat.

Yhteiskunta- ja luonnontieteellisen tutkimuksen rinnalla vielä yksi mahdollinen mutta erilainen vertauskohta Heinon tekemään taiteelliseen tutkimukseen on insinöörien työ, josta Bruno Latour on joskus puhunut "skientifiktiona". Myös insinöörien nerokkuus on kyvyssä yhdistää. He liittävät toisiinsa olemassaolevia tietoja, unelmia, kekseliäisyyttä, tarpeita, kiinnostuksia ja monenlaisia materian muotoja niin, että he voivat onnistua synnyttämään jotain täysin uutta, jotain mitä ei ennen 
ole ollut olemassa mutta mikä saattaa muuttua monen ihmisen arkipäivän olennaiseksi välineeksi - vaikkapa auton, mikroaaltouunin tai kännykän tapaan. Onnistunein insinöörien luomus on sellainen, että se omaksumisen jälkeen sujahtaa elämänmuodon huomaamattomaksi osaksi ja muuttaa sitä sisältä. Taiteellinen tutkimus on toisenlaista skientifiktiota. Se ei muokkaa aikalaiselämänmuotoa leimaavia tapoja ja totunnaisuuksia, kuten insinöörien keksinnöt, mutta parhaimmillaan se voi oivalluksen, hätkähdyksen, innoituksen tai mielihyvän rinnalla tuottaa etäisyyttä ja näkökulmaa tapaan, jolla elämme ja jolla myös hahmotamme elämäämme. Vaikka taiteellinen työ ei olisi ensisijaisesti "teoreettista" vaan ennemminkin hyvin läsnä ja käsillä olevaa kuten Heinon teokset, sen tuloksena voi olla uusi kyky katsoa etäältä, uudenlainen theorein.

Kun on tutustunut tuloksiin, joita Heinon assosiatiivinen työskentely materiaalien kanssa on tuottanut taiteellisissa produktioissa, ei ole yllättynyt siitä, että hänen tekstuaalinen työskentelynsäkin on assosiatiivista. Käsitteellinen työ ei ole kaikilta osin kellosepän tarkkaa - esimerkiksi kysymys dualismista ja antidualismista suhteessa erilaisten ainesten toisiinsa kietoutumiseen olisi ankara ja vaikea työnsarka kelle tahansa filosofille. Silti tämä käsitteellinen työ on tarttuvaa, ja mikä tärkeintä, kiinnostavaa ilman ylilyöntejä. Aristoteleen, Marxin ja Latourin kaltaiset ajattelijat ovat Heinolle ennen muuta innoituksen lähteitä. Heidän suhteensa hän ei ole kokeellinen mutta ei varsinaisesti skolaarinenkaan. Hän ei tarkastele heidän keskinäisiä suhteitaan tai sitä, missä määrin heidän käsitteellistyksensä oikeastaan sopivat yhteen tai eivät sovi. Toisin sanoen taiteellisia teoksia leimaava tarkkuus ja hienovaraisuus assosiaatioiden tekemisessä on astetta karkeampaa käsitteellisen työn kohdalla. Tärkeää kuitenkin on, että Heinon käsitteellinen työ ei tunnu kiusallisesti päälle liimatulta - tätä metaforaa on tässä käytettävä sillä varauksella, että "päälle liimaamisen" merkitys on Heinon työn lukemisen jälkeen uudenlai- nen ja ehkä ennen muuta positiivinen eksperimentaalisuudessaan - vaan ennemminkin elävältä keskustelulta filosofisen ja tutkimuksellisen kirjallisuuden kanssa taiteellisen työn valossa. Kokonaisuuden ydin kuitenkin on tämä kokeellisen taiteellisen työn valo, enemmän kuin tieteen tuoma val(a)istus. Tähän liittyen kiinnostavaa on, että elämänmuodon raja-alueita tutkiva Heino ottaa myös valon, valaisemisen ja reflektion itsensä tutkimuksen kohteiksi. Tässä tutkimisessa valistuksen vaatimus ei yksioikoisesti ohita sitä rikkautta ja epämääräisyyttä, mikä on vaihtelevien varjojen alueella vaan päinvastoin tuo ne meille ilmi, kiinnittää erityisen huomion kontrastien rikkauteen ja monisävyisyyteen.

\section{LOPUKSI}

Taiteellisen työn näkeminen tutkimuksena ei johda sellaiseen reduktiivisuuteen, että täytyisi ajatella kysymyksen olevan vain tutkimuksesta. Synnyttäähän se tekstin lisäksi ennen muuta uusia objekteja, taideobjekteja, joiden maailmassa olemisen rytmi ja luonne on hyvin erilainen kuin tieteellisten tekstien. Aineen olemuksesta materian muuntumiin on itsessään kaunis objekti, sidottu ja kangaspäällysteinen kirja, tyylikkäästi taitettu, nykykustantamojen käytäntöihin nähden poikkeuksellisesti myös huolella oikoluettu. Mikä on sen suhde sen kuvaamiin taideteoksiin? Onko se yksi jäsen taideteosten sarjassa vai jotain ihan muuta? Oikea vastaus on sekä-että. Kirja on sekä taideteoksiin liittyvä niiden uusi osa että viestikapula, joka kulkee niiden välillä ja yhdistää niitä toisiinsa. Aineen olemuksesta materian muuntumiin on vähemmän kuin ne produktiot, joista se kertoo: paljon yksiulotteisempi kuin moniaistisesti koettavat ja käsitettävät installaatiot. Samalla se on myös enemmän kuin taiteelliset työt, kun se sanallisesti kytkee ne niin tekijänsä historiaan, toimiin ja tarkoituksiin, yhteiskuntatieteelliseen ja filosofiseen kirjallisuuteen, taidehistoriaan kuin kysymyk- 
seen siitä, minkälainen on aikalaiselämänmuotomme. Käsitteellinen työ keskustelee taiteellisten produktioiden kanssa. Kumpikin tekee toisesta enemmän kuin mitä ne olisivat yksinään. Taiteen ja tutkimuksen yhdistämisessä Heinon kirja onnistuu siis erinomaisesti.

Aineen olemuksesta materian muuntumiin tuottaa kaikkinensa ainakin neljänlaisia tuloksia. Nämä kietoutuvat toisiinsa. Ensinnäkin se avaa kiinnostavasti sitä käsitteiden kenttää, jolla meille on mielekästä puhua aineesta tai materiaalisuudesta. Toiseksi teos on yksittäisten töiden esittelynä rikas: Heinon installaatioista saa paljon enemmän irti, kun on lukenut hänen käsitteellistyksensä niihin liittyen. Kolmanneksi kirja on kuvaus taiteilijan omasta työskentelystä, sekä sen vaikutteista ja etäisyydenotoista alan perinteeseen ja toimintatapoihin että konkreettisesta tekemisestä. Tällaisena se on valaiseva ohi hänen omien produktioidensa ja varmaan arvokas dokumentaatio myös tuleville taidehistorioitsijoille. Kaikkein tärkeintä mielestäni kirjassa kuitenkin on näistä kaikista kolmesta osittain koostuva mutta silti itsenäinen neljäs asia: kirja on taiteellisen tutkimuksen menetelmillä tuotettu omaperäinen ja avaava kuvaus aikalaiselämäntavastamme ja erityisesti sen suhteesta materiaalisuuteen.

- TURO-KIMMO LEHTONEN 